\title{
US Foreign-Born Essential Workers by Status and State, and the Global Pandemic
}

\author{
Donald Kerwin, Mike Nicholson, Daniela Alulema, and Robert Warren
}

This paper provides comprehensive estimates on immigrant (foreign-born) workers in the United States, employed in "essential critical infrastructure" categories, as defined by the US Department of Homeland Security (DHS) (DHS 2020). It finds that immigrants in the labor force and age 16 and over, work at disproportionate rates in "essential critical infrastructure" jobs. In particular, 69 percent of all immigrants in the labor force and 74 percent of undocumented workers are essential infrastructure workers, compared to 65 percent of the native-born labor force.

The contributions of immigrants to the US labor force and economy have been well-documented. The labor force participation rates of the foreign-born, have long exceeded those of the nativeborn (BLS 2019). Immigrants fill gaps in the US economy, improve labor market efficiency, and support the aging US population (Sherman et al. 2019). Immigration has also "brought to the United States an inordinate share of the world's best talent which has been a windfall in a global economy where heavy advantages accrue to the most innovative companies and countries" (CFR 2009). This paper shows that immigrants, particularly the undocumented, work at high rates in essential critical infrastructure sectors. In the great majority of US states, the foreign-born participate in the essential workforce at higher rates than the native-born, and the foreign-born share of essential workers exceeds the share of all foreign-born workers in the state (Table 1 in appendix). In short, the paper shows that immigrants are working - often at great risk to their health and lives - to keep Americans safe, healthy, fed, and poised for economic recovery.

These findings are at odds with the policies of the current administration, which have consistently sought to divest immigrant populations of legal status and to decrease legal immigration through a variety of administrative measures (Kerwin and Warren 2019), including a recent presidential proclamation to suspend the admission of persons in many legal immigration categories (Trump 2020). In the same vein, the Coronavirus Aid, Relief, and Economic Security Act (CARES Act) denies a federal tax rebate to persons who have filed tax returns without a "valid identification number" (defined as a social security number) or, in the case of a joint return, if either spouse lacks a social security number. ${ }^{1}$ Individual Taxpayer Identification Numbers (ITINs) do not suffice. This requirement will exclude many US taxpaying, mixed-status families - families with undocumented and US citizen family members (typically children) - from obtaining badly needed federal stimulus relief. In 2018, 18.3 million persons lived 3.8 million "mixed-status" households. ITIN filers pay over $\$ 9$ billion in withheld payroll taxes annually and contribute to the solvency of federal retirement programs (Hallman 2018).

\footnotetext{
${ }^{1}$ Coronavirus Aid, Relief, and Economic Security Act (CARES Act), §2201, Pub. L. No. 116-136 (2020). https://www.congress.gov/bill/116th-congress/house-bill/748/text.
} 


\section{Top-line findings}

Based on 2018 US Census data, the Center for Migration Studies (CMS) estimates that 19.8 million immigrants work in "essential critical infrastructure" categories (DHS 2020). ${ }^{2}$ These workers meet the health, infrastructure, manufacturing, service, food, safety, and other needs of all Americans. Roughly one-half of US foreign-born essential workers - 9.6 million - are naturalized citizens, 4.6 million are legal noncitizens (mostly lawful permanent residents or LPRs), and 5.5 million are undocumented. ${ }^{3}$

CMS finds that 69 percent of US immigrant workers - those in the labor force and age 16 and over-work in essential critical infrastructure categories, including 74 percent of undocumented workers, compared to 65 percent of the native-born labor force.

Nationally, foreign-born workers comprise 18 percent of workers in essential critical infrastructure categories. In the overwhelming majority of states, immigrants make up a larger share of essential workers than the native-born, and a larger share than that of all immigrant workers in the state's labor market (Table 1). In California, immigrants comprise 36 percent of essential workers. Foreign-born workers comprise 31 percent of essential workers in both New York and New Jersey. In Florida and Nevada, they make up 28 and 27 percent of essential workers, respectively. They also account for more than 20 percent of essential workers in Texas (24 percent), Hawaii (24 percent), Massachusetts (23 percent), and Maryland (21 percent).

Naturalized citizens make up 67 percent of immigrants working in health care, including 74 percent of immigrants working in hospitals and 74 percent of those working in doctors' and dentists' offices. Many of these immigrants work on the front lines with coronavirus patients.

Undocumented immigrants comprise 54 percent of foreign-born workers in agriculture and farms, and 40 percent in disinfection. These workers contribute to the nation's food security and health. Undocumented immigrants also comprise 50 percent of foreign-born workers in construction, including plumbers and electricians, and the plurality of immigrant workers in tire, rubber, cement, and household appliance manufacturing. These workers will also be vital to the ability of the Americans and the US economy to rebound from the pandemic.

Table 2 provides CMS's estimates of undocumented immigrants, legal non-citizens, and naturalized citizens who work in essential critical infrastructure. A detailed explanation of the methodology used to produce these estimates can be found below.

\footnotetext{
${ }^{2}$ An earlier CMS report produced estimates of immigrants in New York State working in "essential businesses", as identified by the state (not DHS) (Nicholson and Alulema 2020). CMS has also reported on the high number of DACA beneficiaries in select essential industries (Alulema 2020).

${ }^{3}$ CMS's undocumented estimates include two legally present populations, Deferred Action for Childhood Arrivals (DACA) and Temporary Protected Status (TPS) recipients. Nearly one-half of all US foreign-born essential workers are naturalized citizens, while 28 percent are undocumented and 23 percent are legal non-citizens.
} 
In particular, immigrants comprise:

- 16 percent of US health care sector workers. ${ }^{4}$

- 33 percent of health care sector workers in New York State, 32 percent in California, 31 percent in New Jersey, 23 percent in Massachusetts, 17 percent in Illinois, and 9 percent in Pennsylvania; these states have the highest numbers of confirmed coronavirus cases at this writing (CDC 2020).

- 26 percent of home health care workers and aides for the elderly.

- 22 percent of workers in scientific research and laboratories.

- 24 percent of workers in medical equipment manufacturing and 25 percent in pharmaceuticals manufacturing; i.e., businesses that supply the health care sector.

- 28 percent of janitors and building cleaners, 23 percent of workers in disinfection, and 23 percent of those who manufacture soap and cleaning compounds. ${ }^{5}$

- 52 percent of workers in the three industries (immediately above) in California, 44 percent in New Jersey, 40 percent in New York, 39 percent in Massachusetts, 27.5 percent in Illinois, and 14 percent in Pennsylvania.

- 26 percent of construction workers.

- 23 percent of US transportation industry workers, including buses, rails, water transport, and vehicles-for-hire, but excluding airlines.

- 28 percent of workers in telecommunications equipment manufacturing and 31 percent in computer and microelectronic manufacturing.

- 14 percent of workers in automobile and automobile parts manufacturing.

- 21 percent of workers in warehousing, distribution, and fulfillment (i.e., who handle customer orders for e-commerce businesses).

- 31 percent of US agricultural employees, 26 percent of workers in food and beverage manufacturing and processing, 26 percent of grocery wholesalers, and 17 percent in retail grocery and other food and beverage stores.

- 50 percent of workers in the four industries (immediately above) in California, 33 percent in New Jersey, 30 percent in New York, 24 percent in Massachusetts, 20 percent in Illinois, and 13 percent in Pennsylvania.

The 10 essential industries that employ the highest numbers of naturalized citizens include hospitals $(862,400$ workers), restaurants $(741,700)$, construction $(701,600)$, transportation $(571,300)$, building cleaners $(345,400)$, government $(330,200)$, banks $(325,100)$, doctors' and dentists' offices $(309,900)$, nursing homes $(302,100)$, and real estate $(255,900){ }^{6}$

\footnotetext{
${ }^{4}$ A study by the New American Economy provides detailed estimates of immigrant health care workers, and highlights the immense demand for these workers in response to the pandemic (NEA 2020).

${ }^{5}$ This sector also includes cosmetic products.

${ }^{6}$ These essential worker figures are for 2018. While some construction sites and restaurants continue to operate, it is difficult to estimate the precise number of immigrants who continue to work in these sectors.
} 
Undocumented immigrants work - by essential industry - in construction $(1,320,500)$, restaurants $(846,100)$, agriculture and farms $(310,800)$, landscaping $(277,600)$, building cleaners $(268,400)$, food processing and manufacturing $(193,900)$, transportation $(181,000)$, grocery stores $(147,300)$, hotels and other accommodations $(137,000)$, and warehousing, distribution, and fulfillment of online orders $(103,000)$.

\section{Methodology}

To arrive at these estimates, CMS used the "essential critical infrastructure" categories set forth by DHS's Cybersecurity and Infrastructure Security Agency (DHS 2020). DHS sets forth 17 categories of essential critical infrastructure workers. For simplicity and consistency with previous CMS reporting, CMS collapsed these 17 DHS categories into 14 categories that encompass all essential critical infrastructure workers. These 14 categories minimize overlap when matching Census industry codes to DHS categories. ${ }^{7}$

CMS matched each essential category with a 2017 industry code by the Census Bureau. In the few cases where essential infrastructure categories do not correspond to Census Bureau industry codes, CMS matched categories to 2018 Census Bureau occupational codes. ${ }^{8}$ It then calculated the number of workers in each essential industry using 2018 1-Year data from American Community Survey (ACS) data (IPUMS), weighted using individual weights calculated by the Census Bureau (Ruggles et al. 2020). CMS restricted the universe of employees to all individuals aged 16 and over.

Industry codes reflect the industries in which respondents to the ACS most recently performed their occupation. Likewise, occupation codes reflect most recent occupation. To restrict its estimates to individuals that were likely to be working in 2018, CMS included only individuals that were in the labor force at the time they responded to the ACS. Some individuals may work in more than one industry or occupation. For these individuals, the ACS records the industry or occupation in which they earned the most money.

Some industries (construction, restaurants, and hotels, for example) may include high numbers of workers in essential sectors who are not working during the pandemic. Some workers may be furloughed or may have lost their jobs since 2018. These estimates should, thus, be regarded as an upper bound on the number of workers in essential infrastructure by their immigration status as of 2018.

CMS used both industry and occupational codes from the ACS to derive its estimates. Since industry codes encompass many occupations, CMS corrected its estimates for double count.

\footnotetext{
7 In some cases, CMS consolidated the main categories shown in Table 2 to avoid showing small, statistically unreliable numbers. Within each category, the estimates were ranked on total foreign-born, and the smallest categories were summed and shown as other categories. With some exceptions, estimates less than a few thousand are not shown.

8 These categories of essential businesses include corrections, electricians, plumbers, law enforcement, fire prevention and response, building inspection and code enforcement, security, emergency management and response, building cleaners and janitors, disinfection, and logistics.
} 
To estimate the number of naturalized citizens, legal non-citizens, and undocumented immigrants, CMS used information collected in the ACS. The annual series of CMS estimates of undocumented residents includes all the detailed characteristics collected in the ACS (Ruggles et al. 2020). A description of CMS estimation procedures, as well as a discussion of the plausibility of the estimates, is provided in Warren (2020).

\section{References}

Alulema, Daniela. 2020. "DACA Recipients are Essential Workers and Part of the Front-line Response to the COVID-19 Pandemic, as Supreme Court Decision Looms," March 30. New York, NY: Center for Migration Studies. https://cmsny.org/daca-essential-workers-covid/

Centers for Disease Control. 2020. "Cases of Coronavirus Disease in the U.S." Atlanta, Georgia: https://www.cdc.gov/coronavirus/2019-ncov/cases-updates/cases-in-us.html (last visited Apr. 29, 2020).

CFR (Council on Foreign Relations). 2009. "US Immigration Policy." Independent Task Force Report No. 63. New York, NY: CFR. https://www.cfr.org/report/us-immigration-policy

BLS (US Bureau of Labor Statistics). 2019. "Foreign-Born Workers: Labor Force Characteristics- 2018." Washington, DC:

BLS. https://www.bls.gov/news.release/forbrn.nr0.htm/labor-force-characteristics-of-foreignborn-workers-summary

DHS (US Department of Homeland Security, Cybersecurity and Infrastructure Agency). 2020. "Advisory Memorandum on Identification of Essential Critical Infrastructure Workers During Covid-19 Response." Washington, DC:

DHS. https://www.cisa.gov/sites/default/files/publications/Version 3.0 CISA Guidance on Ess ential Critical Infrastructure Workers 4.pdf

Hallman, Hunter. 2018. "How do Undocumented Immigrants Pay Federal Taxes? An Explainer." Washington, DC: Bipartisan Policy Center. https://bipartisanpolicy.org/blog/how-do-

undocumented-immigrants-pay-federal-taxes-an-explainer/

Kerwin, Donald, and Robert Warren. 2019. "Putting Americans First: A Statistical Case for Encouraging Rather than Impeding and Devaluing US Citizenship." Journal on Migration and

Human Security 7(4): 108-22. https://journals.sagepub.com/doi/full/10.1177/2331502419894286

NEA (New American Economy). 2020. "Immigration and Covid-19," updated April 23. New York, NY: NEA. https://research.newamericaneconomy.org/report/immigration-and-covid-19/

Nicholson, Mike, and Daniela Alulema, with Robert Warren and Donald Kerwin. 2020. "Immigrants Comprise 31 Percent of Workers in New York State Essential Businesses and 70 Percent of the State's Undocumented Labor Force Works in Essential Businesses." New York, NY: Center for Migration Studies. https://cmsny.org/new-york-essential-workers/ 
Ruggles, Steven, Sarah Flood, Ronald Goeken, Josiah Grover, Erin Meyer, Jose Pacas and Matthew Sobek. IPUMS USA: Version 10.0 [dataset]. Minneapolis, MN: IPUMS, 2020. https://doi.org/10.18128/D010.V10.0

Sherman, Arloc, Danilo Trisi, Chad Stone, Shelby Gonzalez, and Sharon Parrott. 2019. "Immigrants Contribute Greatly to US Economy, Despite Administration's 'Public Charge' Rule Rationale," August 15. Washington, DC: Center on Budget and Policy

Priorities. https://www.cbpp.org/research/poverty-and-inequality/immigrants-contribute-greatlyto-us-economy-despite-administrations

Trump, Donald. 2020. "Proclamation Suspending Entry of Immigrants Who Present Risk to the US Labor Market During the Economic Recovery Following the COVID-19 Outbreak," April 22. https://www.whitehouse.gov/presidential-actions/proclamation-suspending-entryimmigrants-present-risk-u-s-labor-market-economic-recovery-following-covid-19-outbreak/

Warren, Robert. 2020. "Reverse Migration to Mexico Led to US Undocumented Population Decline: 2010 to 2018." Journal on Migration and Human Security 8 (1): 32-

41. https://journals.sagepub.com/doi/full/10.1177/2331502420906125

\section{Appendix}

\begin{tabular}{|c|c|c|c|c|c|}
\hline \multicolumn{6}{|c|}{ Table 1: Foreign Born Essential Workers by State and Legal Status: 2018} \\
\hline State & $\begin{array}{l}\text { Naturalized } \\
\text { Citizens }\end{array}$ & $\begin{array}{l}\text { Legal Foreign- } \\
\text { Born }\end{array}$ & Undocumented & $\begin{array}{l}\text { Foreign- } \\
\text { Born } \\
\text { Share of } \\
\text { All } \\
\text { Essential } \\
\text { Workers }\end{array}$ & $\begin{array}{l}\text { Foreign- } \\
\text { Born } \\
\text { Share of } \\
\text { Labor } \\
\text { Force }\end{array}$ \\
\hline Total & $9,609,000$ & $4,619,600$ & $5,531,300$ & 18.3 & 17.5 \\
\hline Alabama & 23,300 & 14,700 & 30,100 & 4.5 & 4.5 \\
\hline Alaska & 20,500 & 6,800 & 2,700 & 11.4 & 10.6 \\
\hline Arizona & 183,400 & 104,600 & 133,500 & 18.9 & 17.2 \\
\hline Arkansas & 22,900 & 15,000 & 32,300 & 7.5 & 7.3 \\
\hline California & $2,256,200$ & $1,076,900$ & $1,206,600$ & 35.9 & 33.3 \\
\hline Colorado & 108,400 & 61,300 & 84,600 & 12.9 & 12.0 \\
\hline Connecticut & 116,400 & 54,300 & 58,200 & 18.7 & 18.4 \\
\hline Delaware & 21,300 & 8,400 & 14,200 & 13.2 & 12.1 \\
\hline $\begin{array}{l}\text { District Of } \\
\text { Columbia }\end{array}$ & 16,600 & 14,600 & 10,900 & 18.6 & 16.7 \\
\hline Florida & $1,020,500$ & 474,900 & 396,300 & 28.2 & 26.6 \\
\hline Georgia & 210,000 & 91,100 & 173,600 & 14.1 & 13.7 \\
\hline Hawaii & 70,100 & 33,200 & 18,300 & 23.6 & 22.4 \\
\hline Idaho & 21,500 & 10,700 & 26,000 & 10.2 & 8.6 \\
\hline Illinois & 407,000 & 171,800 & 244,000 & 19.2 & 18.1 \\
\hline Indiana & 63,200 & 37,500 & 52,500 & 6.7 & 6.8 \\
\hline lowa & 35,400 & 28,200 & 29,800 & 8.0 & 7.7 \\
\hline
\end{tabular}




\begin{tabular}{|c|c|c|c|c|c|}
\hline Kansas & 41,600 & 18,200 & 39,700 & 9.8 & 9.5 \\
\hline Kentucky & 32,600 & 19,100 & 26,500 & 5.5 & 5.2 \\
\hline Louisiana & 28,900 & 15,400 & 35,100 & 5.5 & 5.5 \\
\hline Maine & 11,000 & 7,400 & 2,400 & 4.3 & 4.0 \\
\hline Maryland & 237,400 & 90,500 & 118,300 & 21.2 & 20.1 \\
\hline Massachusetts & 291,600 & 149,000 & 88,900 & 22.5 & 20.8 \\
\hline Michigan & 155,400 & 72,400 & 55,400 & 8.4 & 8.2 \\
\hline Minnesota & 118,800 & 61,600 & 48,700 & 11.4 & 10.7 \\
\hline Mississippi & 10,500 & 6,600 & 11,200 & 3.2 & 3.2 \\
\hline Missouri & 60,300 & 27,300 & 24,900 & 5.5 & 5.4 \\
\hline Montana & 5,800 & 2,500 & 1,000 & 2.4 & 2.3 \\
\hline Nebraska & 29,600 & 19,900 & 22,500 & 9.9 & 9.3 \\
\hline Nevada & 127,000 & 51,400 & 84,900 & 27.4 & 25.5 \\
\hline New Hampshire & 21,100 & 7,900 & 2,600 & 6.4 & 6.5 \\
\hline New Jersey & 528,900 & 180,500 & 202,600 & 30.6 & 29.2 \\
\hline New Mexico & 31,000 & 20,700 & 34,400 & 13.5 & 12.1 \\
\hline New York & $1,100,300$ & 480,700 & 360,800 & 31.0 & 28.2 \\
\hline North Carolina & 136,100 & 80,500 & 158,600 & 11.2 & 10.9 \\
\hline North Dakota & 7,100 & 6,000 & 5,200 & 6.0 & 6.3 \\
\hline Ohio & 123,700 & 57,100 & 47,900 & 5.7 & 5.8 \\
\hline Oklahoma & 41,900 & 24,900 & 48,100 & 9.0 & 8.1 \\
\hline Oregon & 85,400 & 43,200 & 72,400 & 14.6 & 13.2 \\
\hline Pennsylvania & 213,900 & 91,100 & 92,800 & 9.1 & 9.2 \\
\hline Rhode Island & 34,000 & 11,500 & 12,100 & 16.4 & 16.2 \\
\hline South Carolina & 45,400 & 26,600 & 40,000 & 6.8 & 6.6 \\
\hline South Dakota & 9,900 & 4,900 & 2,100 & 5.2 & 4.7 \\
\hline Tennessee & 64,000 & 41,200 & 66,900 & 7.7 & 7.1 \\
\hline Texas & 820,800 & 515,200 & 918,500 & 24.0 & 22.4 \\
\hline Utah & 44,800 & 32,000 & 49,800 & 12.9 & 11.2 \\
\hline Vermont & 9,000 & 3,100 & 1,100 & 5.8 & 5.5 \\
\hline Virginia & 244,100 & 92,400 & 144,200 & 17.1 & 16.8 \\
\hline Washington & 232,500 & 116,600 & 148,800 & 19.7 & 18.8 \\
\hline West Virginia & 4,900 & 800 & 2,300 & 1.5 & 1.7 \\
\hline Wisconsin & 60,500 & 35,800 & 43,300 & 6.7 & 6.3 \\
\hline Wyoming & 2,600 & 1,800 & 3,500 & 3.6 & 3.9 \\
\hline
\end{tabular}

Source: Center for Migration Studies of New York. See text for method of estimation. Data collected in the 2018 ACS. 


\begin{tabular}{|c|c|c|c|c|}
\hline \multirow{2}{*}{ Type of worker or economic activity } & \multicolumn{3}{|c|}{ Legal status of foreign-born } & \multirow{2}{*}{$\begin{array}{l}\text { Foreign- } \\
\text { born } \\
\text { share of } \\
\text { essential } \\
\text { workers }\end{array}$} \\
\hline & Naturalized & $\begin{array}{l}\text { Legal } \\
\text { resident }\end{array}$ & $\begin{array}{l}\text { Undoc- } \\
\text { umented }\end{array}$ & \\
\hline Total foreign-born essential workers & $9,609,000$ & $4,619,600$ & $5,531,300$ & 18.3 \\
\hline Essential Health Care Operations & $2,026,900$ & 635,000 & 351,600 & 16.3 \\
\hline Hospitals & 862,400 & 212,000 & 94,800 & 16.1 \\
\hline $\begin{array}{l}\text { Nursing homes or residential health care } \\
\text { facilities or congregate care facilities }\end{array}$ & 302,100 & 115,700 & 78,900 & 16.9 \\
\hline Offices of Doctors and Emergency Dentists & 309,900 & 68,600 & 38,200 & 14.8 \\
\hline $\begin{array}{l}\text { Home Health Care Workers or Aides for } \\
\text { the Elderly }\end{array}$ & 220,000 & 108,000 & 64,600 & 25.7 \\
\hline Walk-In Care Health Facilities & 155,900 & 44,000 & 32,400 & 12.8 \\
\hline Research and Laboratory Services & 78,400 & 46,600 & 24,800 & 22.2 \\
\hline Medical Wholesale and Distribution & 21,400 & 11,300 & 6,300 & 16.2 \\
\hline $\begin{array}{l}\text { Emergency Veterinary and Livestock } \\
\text { Services }\end{array}$ & 10,500 & 5,800 & 2,800 & 5.1 \\
\hline Other essential health care operations & 66,400 & 22,800 & 8,800 & 11.1 \\
\hline Essential Infrastructure & $1,045,800$ & 424,700 & 376,200 & 21.1 \\
\hline $\begin{array}{l}\text { Transportation Infrastructure such as Bus, } \\
\text { Rail, or For-Hire Vehicles, Garages }\end{array}$ & 571,300 & 238,000 & 181,000 & 22.8 \\
\hline Hotels and Places of Accommodation & 238,400 & 105,200 & 137,000 & 30.7 \\
\hline Telecommunications and Data Centers & 90,800 & 36,200 & 31,400 & 15.1 \\
\hline Airports and Airlines & 77,500 & 25,800 & 15,800 & 18.8 \\
\hline $\begin{array}{l}\text { Utilities, Including Power Generation, Fuel } \\
\text { Supply, and Transmission }\end{array}$ & 47,200 & 14,000 & 9,500 & 8.5 \\
\hline Public Water and Wastewater & 20,600 & 5,500 & 1,500 & 8.6 \\
\hline Essential Manufacturing & $1,198,800$ & 699,400 & 857,000 & 20.8 \\
\hline
\end{tabular}




\begin{tabular}{|c|c|c|c|c|}
\hline Agriculture and Farms & 108,800 & 159,900 & 310,800 & 31.3 \\
\hline $\begin{array}{l}\text { Food Processing, Manufacturing Agents, } \\
\text { Including All Foods and Beverages }\end{array}$ & 199,200 & 145,500 & 193,900 & 26.4 \\
\hline Microelectronics, Semi-Conductors & 186,200 & 69,300 & 54,500 & 30.5 \\
\hline $\begin{array}{l}\text { Motor vehicles and motor vehicle } \\
\text { equipment manufacturing }\end{array}$ & 86,000 & 64,200 & 47,200 & 13.6 \\
\hline Medical Equipment and Instruments & 97,400 & 30,900 & 24,000 & 24.2 \\
\hline Pharmaceuticals & 86,400 & 30,600 & 18,500 & 25.2 \\
\hline Aircraft and parts manufacturing & 83,400 & 20,800 & 13,100 & 16.7 \\
\hline Plastics product manufacturing & 35,300 & 19,600 & 23,900 & 17.5 \\
\hline $\begin{array}{l}\text { Electric lighting and electrical equipment } \\
\text { manufacturing, and other electrical } \\
\text { component manufacturing, n.e.c. }\end{array}$ & 42,700 & 16,000 & 14,600 & 20.0 \\
\hline $\begin{array}{l}\text { Miscellaneous fabricated metal products } \\
\text { manufacturing }\end{array}$ & 24,800 & 14,500 & 15,100 & 15.6 \\
\hline Chemicals & 26,800 & 13,800 & 12,100 & 12.1 \\
\hline $\begin{array}{l}\text { Structural metals, and boiler, tank, and } \\
\text { shipping container manufacturing }\end{array}$ & 22,900 & 12,000 & 17,400 & 13.9 \\
\hline Household Paper Products & 24,700 & 10,300 & 13,200 & 12.7 \\
\hline $\begin{array}{l}\text { Machine shops; turned product; screw, nut, } \\
\text { and bolt manufacturing }\end{array}$ & 22,300 & 11,000 & 12,800 & 14.1 \\
\hline Telecommunications & 23,600 & 8,500 & 4,400 & 28.0 \\
\hline Sanitary Products & 15,000 & 11,300 & 7,600 & 23.2 \\
\hline $\begin{array}{l}\text { Iron and steel mills and steel product } \\
\text { manufacturing }\end{array}$ & 15,200 & 7,300 & 10,700 & 11.9 \\
\hline Other essential manufacturing & 98,200 & 53,900 & 63,000 & 12.1 \\
\hline Essential Wholesale & 203,300 & 112,600 & 137,200 & 17.6 \\
\hline $\begin{array}{l}\text { Grocery and related product merchant } \\
\text { wholesalers }\end{array}$ & 81,200 & 56,600 & 76,300 & 26.0 \\
\hline $\begin{array}{l}\text { Household appliances and electrical and } \\
\text { electronic goods merchant wholesalers }\end{array}$ & 21,500 & 11,100 & 7,700 & 18.4 \\
\hline
\end{tabular}




\begin{tabular}{|c|c|c|c|c|}
\hline $\begin{array}{l}\text { Machinery, equipment, and supplies } \\
\text { merchant wholesalers }\end{array}$ & 21,800 & 7,900 & 9,900 & 9.3 \\
\hline $\begin{array}{l}\text { Motor vehicle and motor vehicle parts and } \\
\text { supplies merchant wholesalers }\end{array}$ & 21,200 & 9,800 & 8,100 & 16.2 \\
\hline $\begin{array}{l}\text { Lumber and other construction materials } \\
\text { merchant wholesalers }\end{array}$ & 11,400 & 4,100 & 9,000 & 14.5 \\
\hline $\begin{array}{l}\text { Hardware, and plumbing and heating } \\
\text { equipment, and supplies merchant } \\
\text { wholesalers }\end{array}$ & 10,500 & 5,200 & 3,900 & 11.0 \\
\hline $\begin{array}{l}\text { Petroleum and petroleum products } \\
\text { merchant wholesalers }\end{array}$ & 5,800 & 3,800 & 2,500 & 12.2 \\
\hline $\begin{array}{l}\text { Paper and paper products merchant } \\
\text { wholesalers }\end{array}$ & 4,600 & 1,600 & 2,700 & 15.2 \\
\hline Other essential wholesale & 25,400 & 12,500 & 17,100 & 15.3 \\
\hline Energy & 53,900 & 31,800 & 30,500 & 12.5 \\
\hline Support activities for mining & 25,600 & 19,100 & 18,100 & 14.2 \\
\hline Petroleum refining & 11,700 & 5,400 & 5,500 & 13.8 \\
\hline Oil and gas extraction & 8,400 & 4,500 & 3,400 & 12.6 \\
\hline Other energy workers & 8,100 & 2,700 & 3,500 & 7.5 \\
\hline Essential Retail & $1,228,100$ & 745,400 & $1,085,200$ & 18.4 \\
\hline Restaurants & 741,700 & 516,800 & 846,100 & 20.5 \\
\hline $\begin{array}{l}\text { Grocery Stores including All Food and } \\
\text { Beverage Stores }\end{array}$ & 234,000 & 136,800 & 147,300 & 16.7 \\
\hline Pharmacies & 100,100 & 29,100 & 20,500 & 16.1 \\
\hline Hardware and Building Material Stores & 64,200 & 28,300 & 28,900 & 9.3 \\
\hline Gas Stations & 56,000 & 22,900 & 26,500 & 18.0 \\
\hline Convenience Stores & 28,900 & 10,200 & 13,900 & 15.8 \\
\hline Fuel dealers & 3,300 & 1,300 & 2,200 & 7.3 \\
\hline Essential Services & 761,200 & 461,700 & 661,100 & 20.2 \\
\hline Landscapers & 109,900 & 112,200 & 277,600 & 35.3 \\
\hline
\end{tabular}




\begin{tabular}{|c|c|c|c|c|}
\hline Warehouse, Distribution, and Fulfillment & 125,500 & 93,400 & 103,000 & 21.1 \\
\hline Auto Repair & 130,600 & 73,000 & 102,200 & 17.0 \\
\hline Child Care Services & 144,600 & 80,500 & 66,700 & 18.0 \\
\hline Mail and Shipping Services & 139,000 & 44,700 & 26,800 & 13.5 \\
\hline Laundromats & 42,600 & 21,500 & 42,800 & 37.9 \\
\hline $\begin{array}{l}\text { Trash and Recycling Collection, } \\
\text { Processing, and Disposal }\end{array}$ & 33,900 & 16,400 & 25,700 & 15.8 \\
\hline Personal and Household Goods Repair & 17,400 & 11,300 & 8,000 & 21.1 \\
\hline Animal Shelters & 12,000 & 5,700 & 6,900 & 7.7 \\
\hline $\begin{array}{l}\text { Funeral Homes, Crematoriums, and } \\
\text { Cemeteries }\end{array}$ & 6,000 & 3,100 & 1,500 & 7.1 \\
\hline News Media & 46,700 & 20,600 & 16,600 & 12.2 \\
\hline Financial Institutions & $1,020,900$ & 337,100 & 229,300 & 14.4 \\
\hline Banks & 325,100 & 111,900 & 85,000 & 15.8 \\
\hline Real Estate & 255,900 & 66,000 & 51,800 & 14.6 \\
\hline Services Related to Financial Markets & 166,100 & 65,300 & 41,600 & 14.2 \\
\hline Insurance & 154,400 & 48,900 & 37,800 & 11.8 \\
\hline Payroll and Accounting & 119,400 & 45,000 & 13,000 & 15.0 \\
\hline $\begin{array}{l}\text { Providers of Basic Necessities to } \\
\text { Economically Disadvantaged } \\
\text { Populations and Employees at } \\
\text { Correctional Facilities }\end{array}$ & 223,300 & 81,700 & 38,600 & 14.8 \\
\hline Services to Individuals and Families & 186,000 & 70,700 & 35,500 & 17.8 \\
\hline Food Banks and Shelters & 11,000 & 4,500 & 2,600 & 11.7 \\
\hline Other Providers of Basic Necessities & 26,300 & 6,600 & 400 & 6.4 \\
\hline Construction & 799,800 & 604,100 & $1,398,500$ & 24.8 \\
\hline Construction & 701,600 & 555,900 & $1,320,500$ & 26.0 \\
\hline Electricians & 62,000 & 27,700 & 37,500 & 15.1 \\
\hline Plumbers & 36,200 & 20,500 & 40,500 & 17.2 \\
\hline
\end{tabular}




\begin{tabular}{|c|c|c|c|c|}
\hline Defense & 103,700 & 38,500 & 0 & 9.0 \\
\hline $\begin{array}{l}\text { Essential Services Necessary to } \\
\text { Maintain the Safety, Sanitation, and } \\
\text { Essential Operations of Residences or } \\
\text { Other Essential Businesses }\end{array}$ & 539,600 & 336,800 & 342,200 & 19.1 \\
\hline Building Cleaners or Janitors & 345,400 & 247,300 & 268,400 & 27.9 \\
\hline Security & 80,400 & 33,700 & 24,700 & 13.5 \\
\hline Disinfection & 32,200 & 36,500 & 45,100 & 23.2 \\
\hline Emergency Management and Response & 9,700 & 2,800 & 3,100 & 5.8 \\
\hline $\begin{array}{l}\text { Other Essential Services Necessary to } \\
\text { Maintain Safety, Sanitation, and Essential } \\
\text { Operations }\end{array}$ & 71,900 & 16,500 & 900 & 5.9 \\
\hline $\begin{array}{l}\text { Vendors that Provide Essential Services } \\
\text { or Products, Including Logistics and } \\
\text { Technology Support }\end{array}$ & 357,100 & 90,200 & 7,300 & 9.8 \\
\hline
\end{tabular}




\begin{tabular}{|c|c|c|c|c|c|c|c|c|c|c|c|c|}
\hline \multicolumn{13}{|c|}{ Table 3: Foreign-Born Essential Workers by Select States and Industries } \\
\hline & California & Florida & Hawaii & Illinois & Maryland & Mass. & Mich. & Nevada & $\begin{array}{r}\text { New } \\
\text { Jersey }\end{array}$ & $\begin{array}{l}\text { New } \\
\text { York }\end{array}$ & Penn. & Texas \\
\hline \multicolumn{13}{|l|}{ Number of: } \\
\hline $\begin{array}{l}\text { Health Care } \\
\text { Workers }\end{array}$ & 597,700 & 313,900 & 16,700 & 122,900 & 100,000 & 124,100 & 50,200 & 30,700 & 168,300 & 409,000 & 82,200 & 260,600 \\
\hline $\begin{array}{l}\text { Janitors and } \\
\text { Building Cleaners }\end{array}$ & 173,000 & 86,900 & 5,000 & 36,400 & 17,900 & 24,200 & 5,200 & 16,100 & 36,600 & 100,300 & 17,500 & 105,600 \\
\hline $\begin{array}{l}\text { Workers in } \\
\text { Disinfection }\end{array}$ & 33,100 & 12,300 & 1,400 & 2,800 & 700 & 3,400 & 1,000 & 2,500 & 3,200 & 7,500 & 2,000 & 15,100 \\
\hline $\begin{array}{l}\text { Workers in } \\
\text { Agriculture }\end{array}$ & 291,093 & 35,346 & 2,540 & 3,982 & 1,010 & 1,096 & 5,330 & 1,237 & 3,675 & 6,454 & 7,334 & 32,198 \\
\hline $\begin{array}{l}\text { Workers in Food } \\
\text { and Beverage } \\
\text { Manufacturing }\end{array}$ & 112,800 & 22,800 & 1,700 & 29,600 & 3,100 & 10,200 & 9,400 & 3,300 & 20,300 & 21,900 & 16,600 & 44,600 \\
\hline $\begin{array}{l}\text { Workers in } \\
\text { Transport (Except } \\
\text { Airlines) }\end{array}$ & 225,700 & 111,500 & 5,900 & 60,400 & 18,300 & 22,000 & 12,900 & 13,300 & 51,500 & 159,200 & 18,600 & 100,100 \\
\hline \multicolumn{13}{|l|}{$\begin{array}{l}\text { Percentage of } \\
\text { all: }\end{array}$} \\
\hline $\begin{array}{l}\text { Health Care } \\
\text { Workers }\end{array}$ & 31.6 & 27.7 & 24.2 & 16.7 & 24.6 & 23.3 & 8.2 & 24.8 & 30.7 & 32.9 & 9.2 & 18.6 \\
\hline $\begin{array}{l}\text { Janitors and } \\
\text { Building Cleaners }\end{array}$ & 52.4 & 41.9 & 31.6 & 28.7 & 32.2 & 39.1 & 4.9 & 51.2 & 46.9 & 40.8 & 13.7 & 41.1 \\
\hline $\begin{array}{l}\text { Workers in } \\
\text { Disinfection }\end{array}$ & 53.7 & 30.5 & 39.2 & 16.8 & 12.7 & 36.2 & 5.9 & 47.3 & 38.6 & 32.7 & 12.8 & 31.6 \\
\hline $\begin{array}{l}\text { Workers in } \\
\text { Agriculture }\end{array}$ & 68.4 & 48.2 & 35.1 & 7.3 & 8.6 & 10.9 & 12.9 & 19.2 & 32.1 & 15.6 & 14.9 & 30.0 \\
\hline $\begin{array}{l}\text { Workers in Food } \\
\text { and Beverage } \\
\text { Manufacturing }\end{array}$ & 44.1 & 37.7 & 32.6 & 27.0 & 15.5 & 38.5 & 19.8 & 35.7 & 45.5 & 29.6 & 18.5 & 33.6 \\
\hline
\end{tabular}




\begin{tabular}{|c|c|c|c|c|c|c|c|c|c|c|c|c|}
\hline $\begin{array}{l}\text { Workers in } \\
\text { Transport (Except } \\
\text { Airlines) }\end{array}$ & 42.5 & 38.1 & 31.8 & 25.9 & 22.9 & 30.8 & 12.3 & 27.7 & 36.7 & 47.1 & 10.3 & 25.3 \\
\hline
\end{tabular}

